\title{
Synthesis of Biogenic Silver Nanoparticles with Eco-Friendly Processes Using Ganoderma lucidum Extract and Evaluation of Their Theranostic Applications
}

\author{
Vinh Phu Nguyen, ${ }^{1,2}$ Hieu Le Trung, ${ }^{1}$ Thu Huong Nguyen, ${ }^{1}$ DongQuy Hoang $\mathbb{D}^{3,}, 4$ \\ and Thai Hoa Tran $\mathbb{D D}^{1}$ \\ ${ }^{1}$ Department of Chemistry, University of Sciences, Hue University, 77 Nguyen Hue Street, Hue City 530000, Vietnam \\ ${ }^{2}$ Faculty of Basic Sciences, University of Medicine and Pharmacy, Hue University, 06 Ngo Quyen Street, Hue City 530000, Vietnam \\ ${ }^{3}$ Faculty of Materials Science and Technology, University of Science, Vietnam National University Ho Chi Minh City, \\ 700000, Vietnam \\ ${ }^{4}$ Vietnam National University Ho Chi Minh City, 700000, Vietnam
}

Correspondence should be addressed to DongQuy Hoang; htdquy@hcmus.edu.vn and Thai Hoa Tran; tthaihoa@hueuni.edu.vn

Received 16 April 2021; Accepted 16 July 2021; Published 4 August 2021

Academic Editor: Dong kee Yi

Copyright (c) 2021 Vinh Phu Nguyen et al. This is an open access article distributed under the Creative Commons Attribution License, which permits unrestricted use, distribution, and reproduction in any medium, provided the original work is properly cited.

\begin{abstract}
The green synthesis of silver nanoparticles (AgNPs) using plant extract, the cost-effective solution, and the abundance and environmental issue have been gaining much attention to scientists. Ganoderma lucidum (GL) commonly known as Lingzhi in Chinese and Reishi in Japanese, with a proven anticancer benefit, is discovered in the buffer zone of Bach Ma National Park, Nam Dong district, Thua Thien Hue province. In this work, the AgNPs were synthesized in a simple and effective biochemical reduction process using GL which is one of the biological organisms, as a reducing and stable agent. The optimum conditions of various experimental parameters such as $\mathrm{pH}$, reaction time, concentration, and temperature were investigated. Obtained AgNPs were characterized by UV-Vis, FTIR, SEM, energy-dispersive X-ray spectroscopy (EDX), X-ray diffraction (XRD), and transmission electron microscopy (TEM). The effects of AgNP/GL materials and GL aqueous extraction on the antiproliferative activities of HepG2 and MCF-7 cells were studied. The novel AgNP/GL-based multicomponent suspension is a key compound that could find a good application in the medical and pharmaceutical sciences.
\end{abstract}

\section{Introduction}

Cancer is a disease caused when the normal cell proliferation control is lost. Human hepatocellular carcinoma (HepG2) is one of the types of cancer which causes a number of deaths with cirrhosis in each year [1]. Besides, breast cancer (MCF-7) is the cancer that forms in the cells of the breast and immense among women in the world, recording the second public inception of death in women with $16 \%$ of all female cancers [2]. In recent years, although there are a number of methods for treating cancer disease, they spend a lot of money cost and have more weak points such as the limitation on distinguishing between normal and diseased cells and elimination from the human body [3]. To solve this phenom- enon, developing a new material with the ability to hold and release drugs in environments with suitable $\mathrm{pH}$ and temperature is essential [4]. Metal nanomaterials have received a great deal of scientist's concern [5].

Noble metal nanomaterials such as $\mathrm{Au}, \mathrm{Ag}$, and $\mathrm{Pt}$ with size particles between 1 and 100 nanometers have distinguished properties such as the chemical and optical properties due to a surface plasmon resonance (SPR) [6-9]. Silver metal has attracted substantial attention because of a potential application in different areas such as antibacterial agents, catalysis, biological and chemical sensors, water treatment, and biomedicine [10-14]. Besides, the nanosized silver particles (AgNPs) have the ability to inhibit a variety of cancer cells especially HepG2 and MCF-7 $[15,16]$ and the 


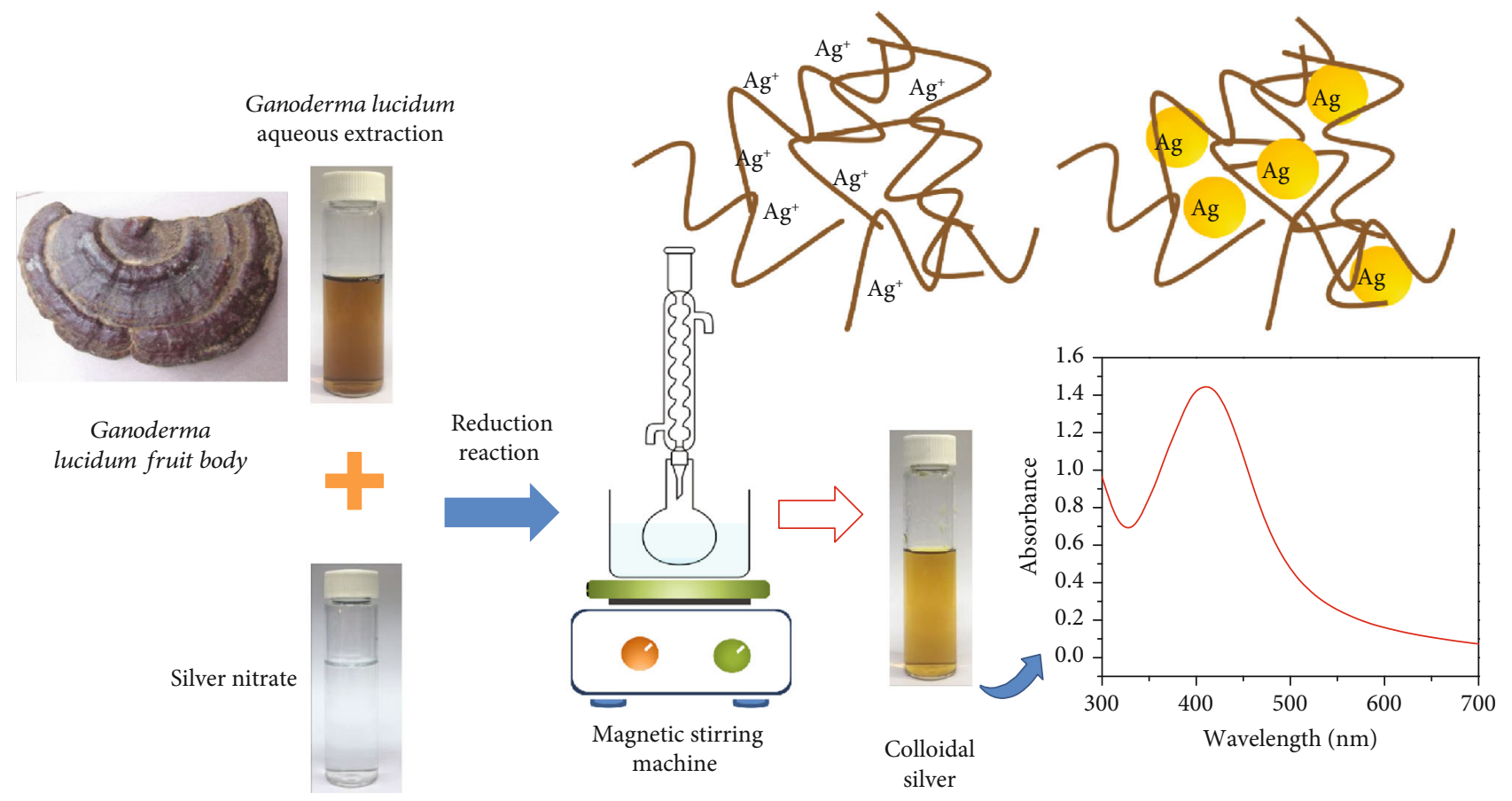

FIgURE 1: Schematic diagram of the biosynthesis of AgNPs using aqueous extract of GL.

anticancer activity of AgNPs was dependent on the size, shape, and surface charge of these particles [17].

In general, the AgNPs are synthesized by two main methods: the physical and chemical methods [18]. Although the particles synthesized by these two methods have defined shape and size, the procedures require a lot of expensive equipment and often use toxic and hazardous chemicals, which are considered highly harmful to human health [19, 20]. Hence, a novel green strategy for producing AgNPs has been developed by using extracted solutions from natural resources such as bacteria [21], fungi [22, 23], marine algae [24], lichens [25], and plants [26]. These extracted solutions not only are biocompatible and nontoxic to the human body but also play an important factor in reducing and protecting agents in the process of synthesis of AgNPs [27, 28]. Moreover, this method also provides an advance over other methods because it could be cataloged, eco-friendly, and low cost [29].

Ganoderma lucidum (GL) has been known as a medical mushroom and applied to traditional medicine for past centuries [30] and is one of the biological resources for the synthesis AgNPs. Although GL contains different natural compounds, polysaccharide and triterpenoids are the most important components [31] and these compounds cause biological activities such as antiallergic [32], anti-inflammatory [33], antiviral [34], anticancer [35], and antidiabetes [36], which contributes to health benefits.

In this research, the AgNPs were synthesized by the "green method" and the process was carried out by a reduction reaction of silver nitrate using the aqueous extraction of G. lucidum as a reducing and protecting agent. This research focused on the impact of the reaction parameters such as temperature, time, concentration of silver nitrate, and $\mathrm{pH}$ value. The AgNPs were characterized in the aspects of the morphological properties, structure, and size distribution. The preliminary in vitro cytotoxicity was investigated on both human hepatocellular carcinoma (HepG2) and human breast cancer cell (MCF-7) via the MTT method.

\section{Experimental Methods}

2.1. Materials. The fruit bodies of GL collected from the buffer zone of Bach Ma National Park from Nam Dong district, Thua Thien Hue province, were dried and ground into powder.

Silver nitrate $\left(\mathrm{AgNO}_{3} \cdot 5 \mathrm{H}_{2} \mathrm{O}, 98 \%\right)$, ammonium hydroxide $\left(\mathrm{NH}_{4} \mathrm{OH}, 25 \%\right)$, nitric acid $\left(\mathrm{HNO}_{3}, 90 \%\right)$, and ethanol $\left(\mathrm{C}_{2} \mathrm{H}_{5} \mathrm{OH}, 98 \%\right)$ were purchased from Xilong Chemical Co., Ltd. Human hepatocellular carcinoma (HepG2) and human breast carcinoma (MCF-7), Dulbecco's modified Eagle's medium (DMEM), fetal bovine serum (FBS), penicillin, streptomycin, 3-(4,5-dimethylthiazol-2-yl)-2,5-diphenyltetrazolium bromide (MTT), and dimethyl sulfoxide (DMSO) were purchased from Sigma-Aldrich Chemical Company, USA. All chemicals were used without further purification.

2.2. Preparation of Aqueous Extraction of Ganoderma lucidum. Aqueous extraction of GL was prepared by using the reflux method [37]. A $2.0 \mathrm{~g}$ of mushroom powder was added to $200 \mathrm{~mL}$ of distilled water. The mixture was heated to $85^{\circ} \mathrm{C}$ for $4 \mathrm{~h}$ under stirring condition. A yellowish solution was then centrifuged with $4300 \mathrm{rpm}$ for $20 \mathrm{~min}$. The solution was concentrated to $50 \mathrm{~mL}$. In addition, four times the volume of $96 \%$ ethanol was added to the concentrated solution. The mixture was placed in a refrigerator for $24 \mathrm{~h}$, 


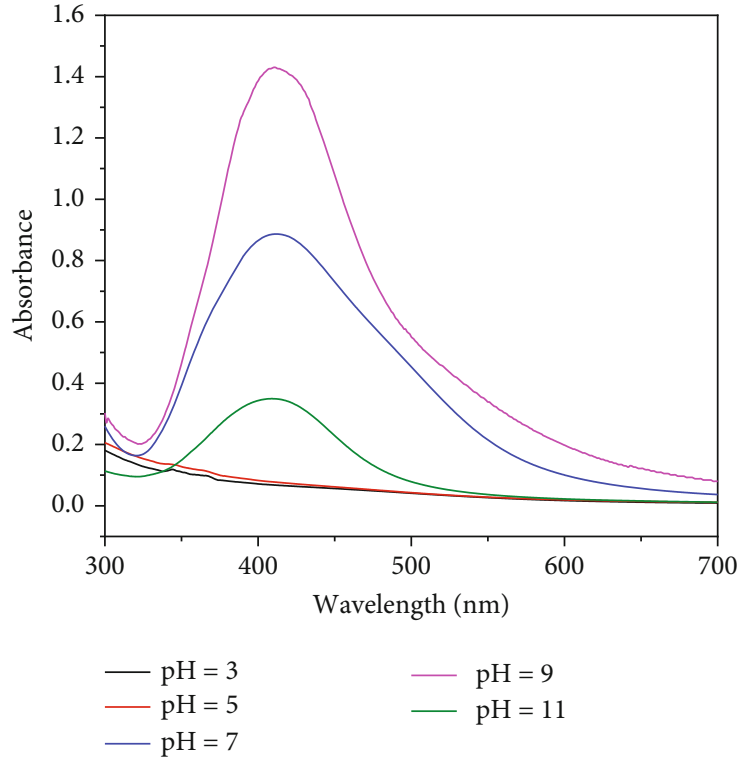

(a)

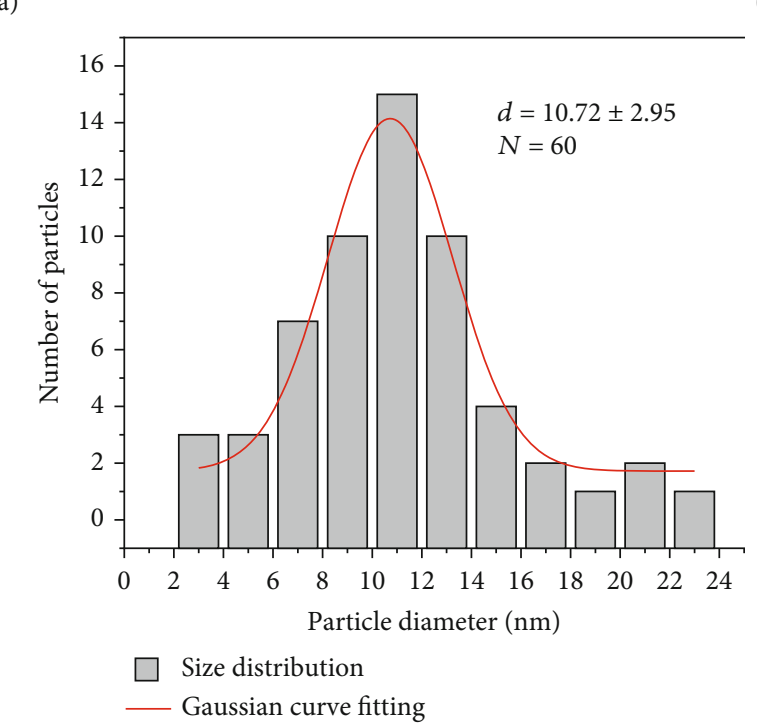

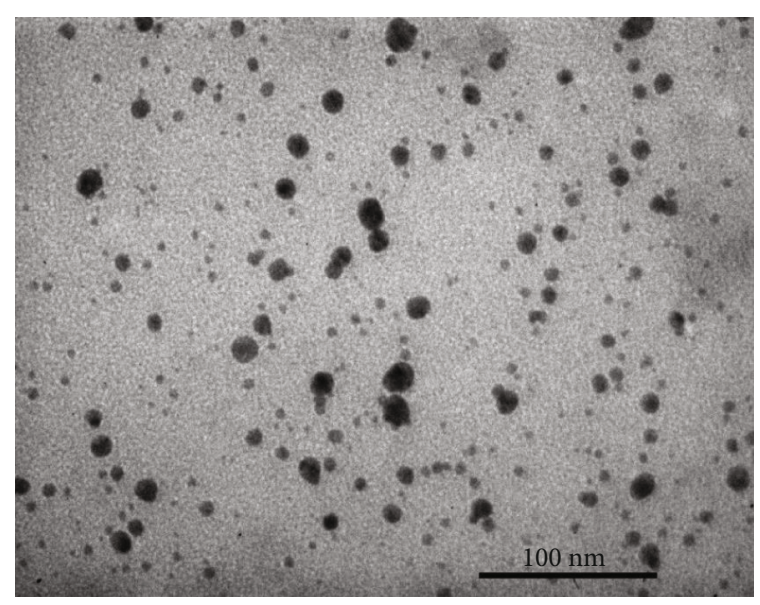

(b)

(c)

FIgURE 2: (a) UV-Vis spectra of AgNPs/GL obtained with different pH values; (b) TEM image of AgNPs/GL with pH 9; (c) histogram size distribution curve of AgNPs/GL ( $\mathrm{pH}$ 9).

subsequently centrifuging (4300 rpm, $20 \mathrm{~min})$. The precipitate was washed with acetone and dried at $75^{\circ} \mathrm{C}$ for $6 \mathrm{~h}$. The dried aqueous extraction was stored for further experiments.

2.3. Biosynthesis of Silver Nanoparticles. In a typical process, the dry aqueous extract of G. lucidum was redissolved in distilled water to obtain an aqueous extraction solution of GL (A-GL) with a concentration of $1 \mathrm{~g} \cdot \mathrm{mL}^{-1} .90 \mathrm{~mL}$ of this solution was mixed with $10 \mathrm{~mL}$ aqueous solution of silver nitrate with different concentrations. The reaction mixture was conducted under the stirring condition at $120 \mathrm{rpm}$. The $\mathrm{pH}$ of the mixture was adjusted by adding dropwise ammonia solution $(25 \%, v / v)$ or nitric acid solution $0.01 \mathrm{M}$. The optimum condition for the synthesis process of AgNPs was studied by varying some reaction factors such as $\mathrm{pH}(3,5,7,9$, and $11)$, time $(0.5$ to $7 \mathrm{~h})$, concentration of silver nitrate $(0.5,1$, and $1.5 \mathrm{mM})$, and reaction temperature $(65,75,85$, and $95^{\circ} \mathrm{C}$ ). To obtain AgNPs, the suspension was precipitated overnight by ethanol $95 \%(v / v)$, followed by centrifugation (4000 rpm, $20 \mathrm{~min}$ ). The precipitate was dried at $75^{\circ} \mathrm{C}$ under vacuum for $24 \mathrm{~h}$. The obtained pellets were symbolized as AgNPs/GL and stored for further studies.

2.4. Characterization of Silver Nanoparticles. The optical properties of AgNPs/GL were investigated by measuring optical absorption spectra in the UV-Vis region with a V630 spectrometer. The crystal phase of products was characterized by X-ray diffraction (XRD, D8-BRUKER, Germany) equipped with $\mathrm{Cu} \mathrm{K} \alpha$ radiation $(\lambda=1.5406 \AA)$. The morphology and particle size distribution of the synthesis products were observed by transmission electron microscopy (TEM, JEOL-1010, Japan); also, the surface characteristics 


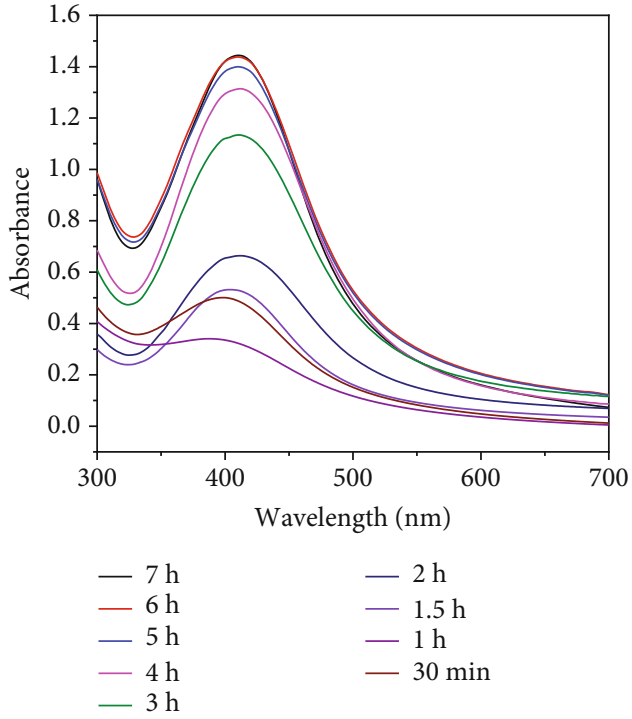

Figure 3: UV-Vis spectra of AgNPs/GL obtained at different time intervals $(30 \mathrm{~min}-7 \mathrm{~h})$.

were assessed using a scanning electron microscope (SEM) (JEOL JSM-6510, Japan). The presence of silver elements was confirmed by energy-dispersive X-ray spectroscopy (EDX). To investigate the functional groups of both A-GL and AgNPs/GL, a Fourier-transform infrared (FTIR) study was carried out with the R-Prestige-21 Shimadzu FTIR spectrophotometer, using $\mathrm{KBr}$ pellet method.

\subsection{Cell Culture and Cytotoxicity Studies}

2.5.1. Culture of Cells. HepG2 and MCF-7 cells were cultivated in DMEM medium, complemented with $10 \%$ FBS, penicillin $(100 \mathrm{U} / \mathrm{mL})$, and streptomycin $(100 \mu \mathrm{g} / \mathrm{mL})$ in the standard condition $\left(37^{\circ} \mathrm{C}, 98 \%\right.$ humidity, $5 \% \mathrm{CO}_{2}$, and absolutely sterile). After $24 \mathrm{~h}$ incubation, the cells were trypsinized, centrifuged, and washed with sterile PBS buffer solution. The viable cell count and viability were estimated using Trypan blue exclusion method. These cells having the viabilities above 95\% were used to study the cytotoxicity assessment [38].

2.5.2. Cytotoxicity Assessment by MTT Assay. Firstly, the cytotoxic activities of G. lucidum aqueous extract and AgNPs/GL on HepG2 and MCF-7 were determined using MTT assay [39, 40]; the tumor cells were seeded with density $3 \times 10^{4}$ cells $/ \mathrm{mL}$ in 96-well plates and each well was filled with $200 \mu \mathrm{L}$ of cell suspension (HepG2 and MCF-7). This was followed by incubation of plates at $37^{\circ} \mathrm{C}$ with $5 \% \mathrm{CO}_{2}$ overnight to allow cell attachment. After that, the G. lucidum aqueous extract and AgNP/GL suspension with the concentrations of $2,8,32$, and $128 \mu \mathrm{g} \cdot \mathrm{mL}^{-1}$ were added into appropriate wells. These wells were incubated at $37^{\circ} \mathrm{C}, 5 \% \mathrm{CO}_{2}$ in $72 \mathrm{~h}$. The control sample and blank sample were the well with culture medium and the well containing cells without samples, respectively. The experiments were repeated three times for validity. After the incubation period, $200 \mu \mathrm{L}$ of MTT $\left(5 \mathrm{mg} \cdot \mathrm{L}^{-1}\right)$ was added to each well and it was continuously incubated for $4 \mathrm{~h}$. The culture medium was removed, and

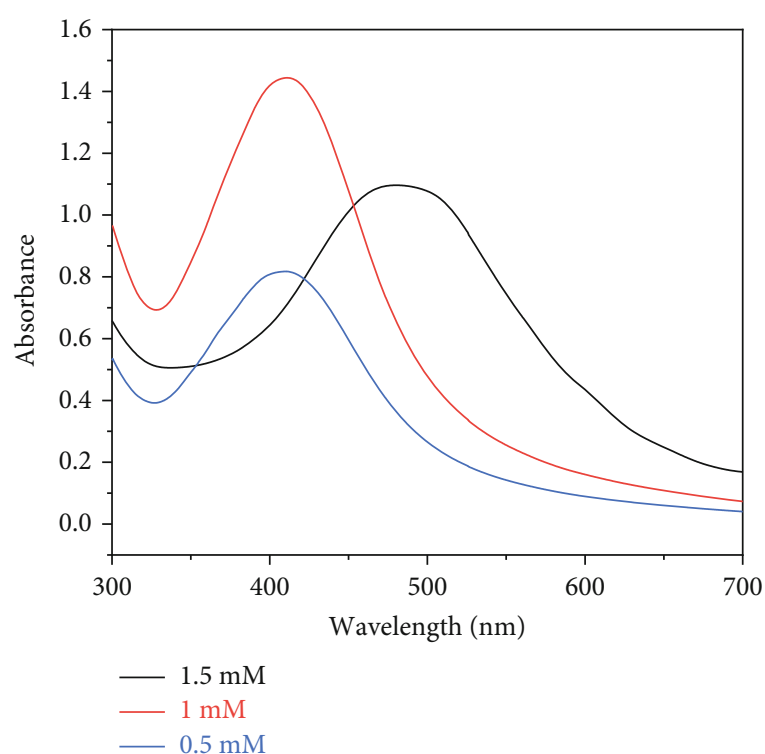

(a)

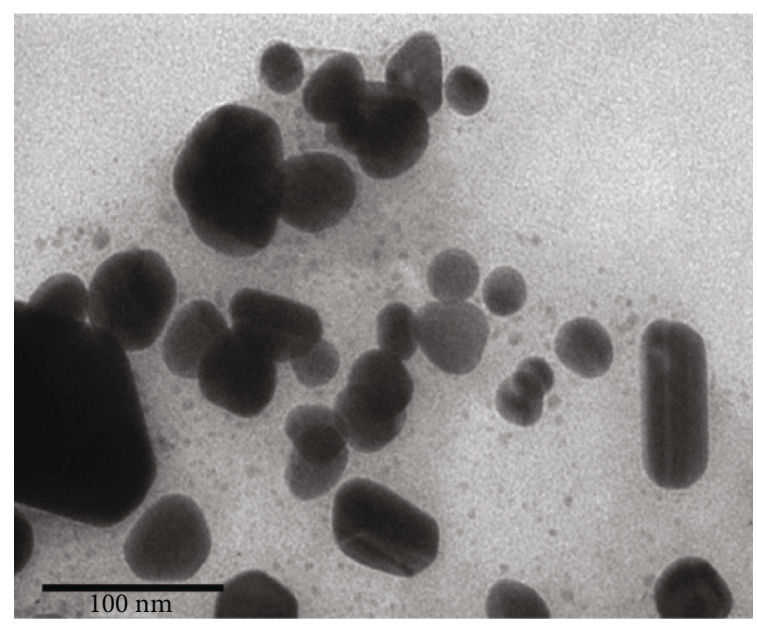

(b)

FIgUre 4: (a) UV-Vis spectra of AgNPs/GL obtained by varying the concentration of silver nitrate $(0.5-1.5 \mathrm{mM})$. (b) TEM image of AgNPs/GL with $C_{\mathrm{AgNO}_{3}}=1.5 \mathrm{mM}$.

$100 \mu \mathrm{L}$ of DMSO was added to each well. The TECAN microplate reader was used to measure the absorbance of each well at the wavelength $540 \mathrm{~nm}$. The proliferation of each cell line was expressed by the percentage of cell viability.

Each concentration of treated cells, control sample, and blank sample was repeated three times for validity. After $72 \mathrm{~h}, 200 \mu \mathrm{L}$ of MTT $\left(5 \mathrm{mg} \cdot \mathrm{L}^{-1}\right)$ was added to each well and it was incubated for $4 \mathrm{~h}$. The medium was removed, and $100 \mu \mathrm{L}$ of DMSO was added to each well. The absorbance of the 96-well plates was measured at $540 \mathrm{~nm}$ using a TECAN microplate reader. The effect of the sample on the proliferation of HepG2 and MCF-7 was expressed as the percentage of growth inhibition cell, using the following formula:

$$
\% \text { Inhibition }=\frac{A_{\text {treated cell }}-A_{\text {blank }}}{A_{\text {control }}-A_{\text {blank }}} \cdot 100 \% \text {, }
$$




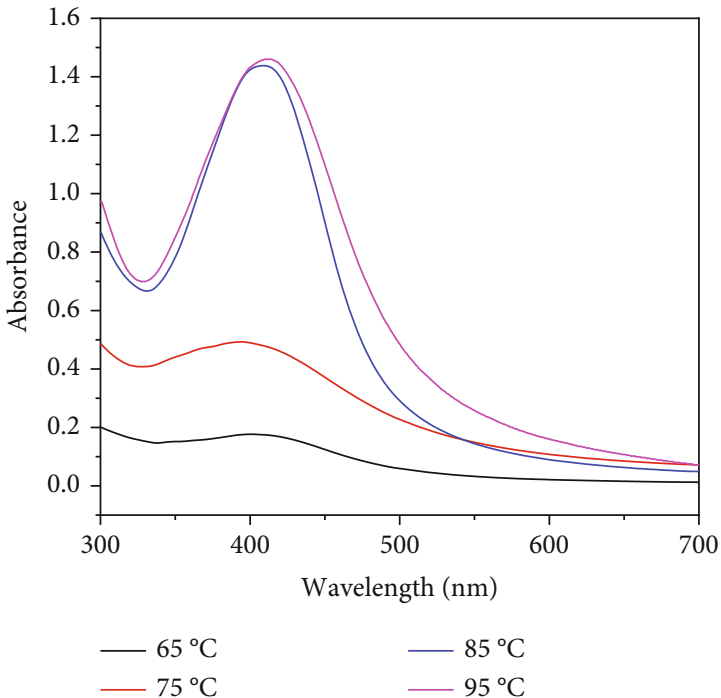

Figure 5: UV-Vis spectra of AgNPs/GL obtained by varying the temperature reaction from 65 to $95^{\circ} \mathrm{C}$.

TABle 1: The maximum absorbance of sample at different temperatures and storage times.

\begin{tabular}{lcccc}
\hline $\begin{array}{l}\text { Temperature } \\
\left({ }^{\circ} \mathrm{C}\right)\end{array}$ & Initially & $\begin{array}{c}2 \\
\text { weeks }\end{array}$ & 4 weeks & 6 weeks \\
\hline 65 & 0.1764 & 0.1464 & 0.1032 & Agglomeration \\
75 & 0.4924 & 0.4124 & Agglomeration & Agglomeration \\
85 & 1.4374 & 1.4314 & 1.4234 & 1.4144 \\
95 & 1.4597 & 1.4317 & 1.4226 & 1.3882 \\
\hline
\end{tabular}

where $A_{\text {treated cell }}, A_{\text {control }}$, and $A_{\text {blank }}$ were absorbance peaks of treated cell sample, control sample, and blank sample, respectively. $\mathrm{IC}_{50}$ values were defined as sample concentration inhibiting $50 \%$ of cell growth, and they were obtained from the linear regression of calibration curve by using Microsoft Excel software.

\section{Results and Discussion}

3.1. Visual Observation. The process of biosynthesis of AgNPs/GL is shown in Figure 1. The color of the GL aqueous extract was yellow before its treatment with silver nitrate solution. After reaction, the color of the mixture became dark brown. This observation is contributed to confirm the formation of AgNPs due to the surface plasmon resonance. Moreover, the UV-Vis spectra of samples had the surface plasmon resonance peak of mixture reaction at a wavelength around $407 \mathrm{~nm}$, which indicates the formation of AgNPs.

3.2. Reaction Condition Optimization. The $\mathrm{pH}$ was investigated in order to find the suitable $\mathrm{pH}$ for the formation of AgNPs. The $\mathrm{pH}$ of the solution was adjusted from its original value of $\mathrm{pH} 7$ to the desired $\mathrm{pH}(3,5,9$, and 11) by a dropwise addition of nitric acid $\left(\mathrm{HNO}_{3}\right)$ or ammonium hydroxide $\left(\mathrm{NH}_{4} \mathrm{OH}\right)$ dilute solutions. The other chemical parameters were constant: $C_{\mathrm{AgNO}_{3}}=1 \mathrm{mM}$, reaction time: $4 \mathrm{~h}$, and reaction temperature: $75^{\circ} \mathrm{C}$. The UV-Vis spectra of samples in

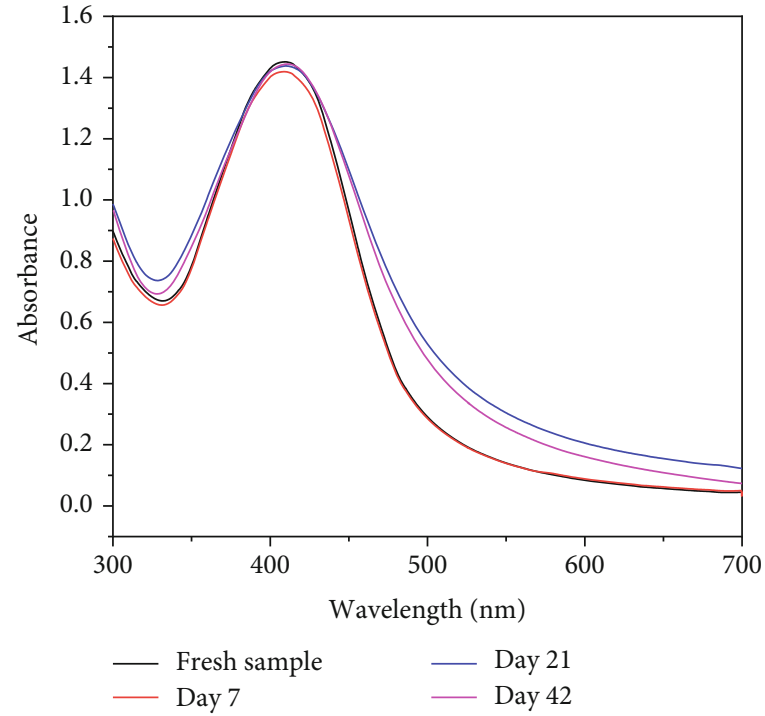

FIgURE 6: UV-Vis spectra of AgNP/GL colloidal solution at different storage times.

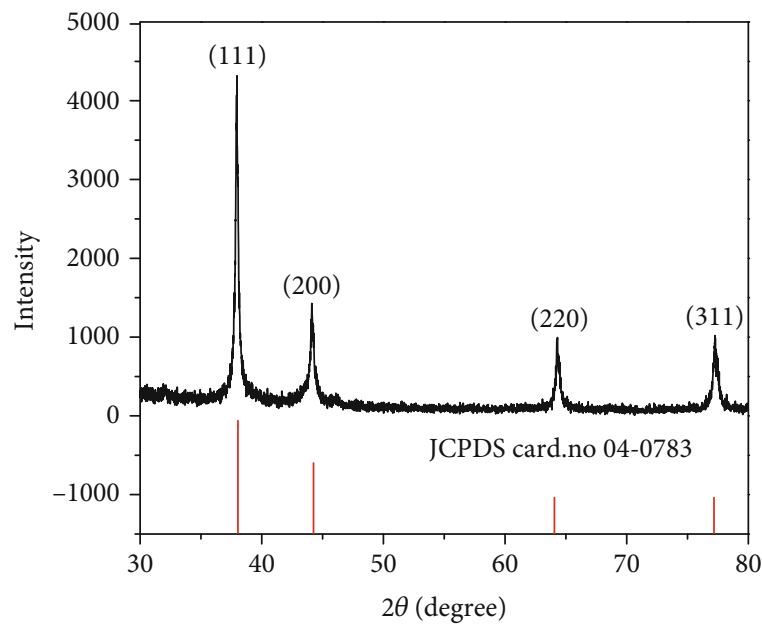

FIGURE 7: XRD pattern of AgNPs/GL.

different $\mathrm{pH}$ are shown in Figure 2(a). At the $\mathrm{pH}$ values of 3 and 5, the SPR peaks were not detected, indicating that the acidic condition was not suitable for generating the AgNPs. This phenomenon could be explained that the reducing power of these functional groups such as hydroxyl and carbonyl in the acidic environment is declined and so that it cannot be able to reduce silver ions [41]. Besides, in the $\mathrm{pH}$ range from 7 to 11, the color of AgNPs was turned to deep brown and the UV-Vis spectra presented SPR peaks from 405 to $415 \mathrm{~nm}$, demonstrating that the AgNPs were formed. In neutral and alkaline conditions, both reducing and protecting abilities become more efficient. Therefore, more silver nanoparticles were generated and the agglomeration between these particles was prevented [41, 42]. By comparing the shape and peak intensities between UV-Vis spectra, the sample synthesized at $\mathrm{pH} 9$ was narrow and had the highest intensity. Thus, the synthesis process of AgNPs achieved a high performance and these particles were 


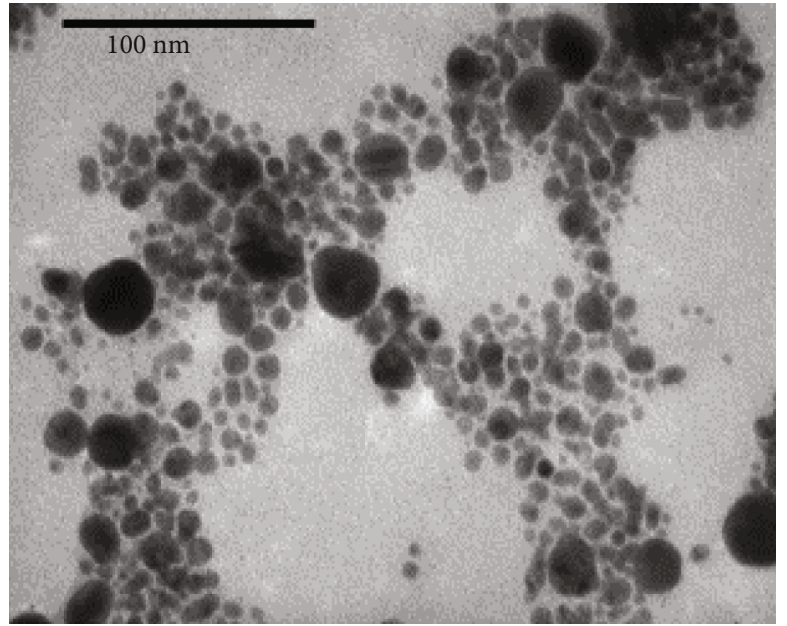

(a)

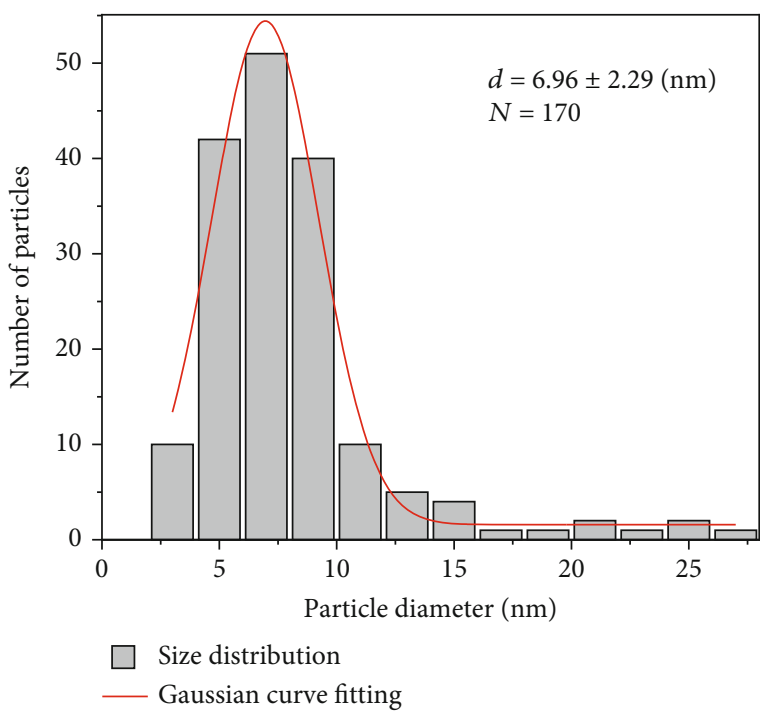

(b)

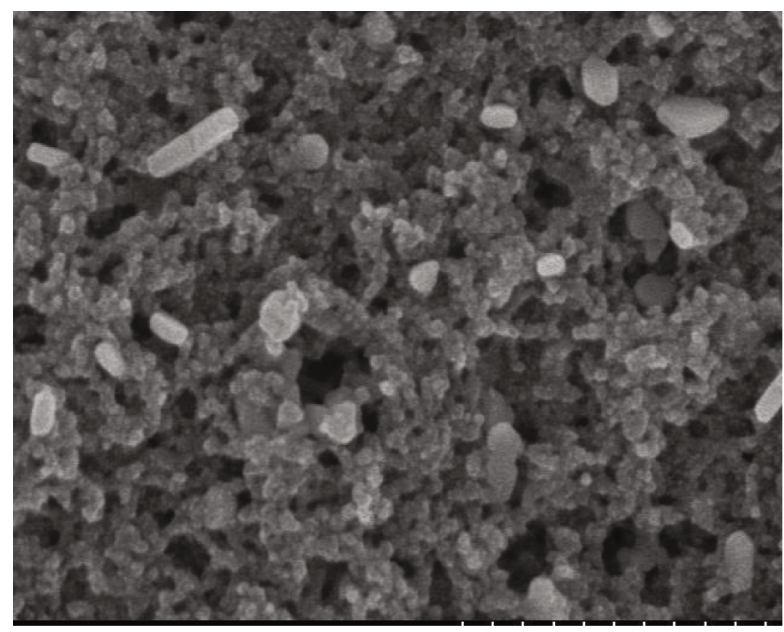

(c)

Figure 8: (a) TEM image of AgNPs/GL. (b) Particle diameter of AgNPs/GL. (c) SEM image of AgNPs/GL.

obtained with uniform size distribution. Hence, the alkaline condition was suitable for synthesizing AgNPs and pH 9 was selected as the optimum $\mathrm{pH}$ value. The morphology and particle size of AgNPs/GL synthesized with pH 9 were confirmed by TEM image and shown in Figure 2(b). It can be seen that the AgNPs/GL obtained was spherical and uniform. The histogram size distribution curve of AgNPs/GL ( $\mathrm{pH}$ 9) is shown in Figure 2(c) with the particle size around $10.72 \mathrm{~nm}$.

In the process synthesis of AgNPs/GL, reaction time was also an important parameter. Therefore, reaction time was studied with the other factors keeping intact: $C_{\mathrm{AgNO}_{3}}=1$ $\mathrm{mM}$, reaction temperature: $75^{\circ} \mathrm{C}$, and $\mathrm{pH} 9$ (optimum $\mathrm{pH}$ ). Figure 3 shows the absorption spectra of AgNPs at different reaction times from $30 \mathrm{~min}$ to $7 \mathrm{~h}$. It is clear that in the first $30 \mathrm{~min}$, the UV-Vis spectrum shows a broader peak with a lower intensity. By increasing the reaction time, the solution changed from pale-yellow to brown and dark brown and the intensity of peaks was also increased, which indicates that the AgNPs were generated continuously. From 5 to $7 \mathrm{~h}$, the intensity peak at $\lambda_{\max }$ value $(407 \mathrm{~nm})$ slightly increased and remained unchanged at $6 \mathrm{~h}$ so that this leads to the completion of AgNP formation in this solution. Therefore, the optimum reaction time was $6 \mathrm{~h}$ and chosen for further studies.

The concentration of silver nitrate is one of the important parameters affecting the size and productivity of AgNPs. In terms of studying the effect of ion silver, the concentration of ion silver is varied from 0.5 to $1.5 \mathrm{mM}$ and the other exper-

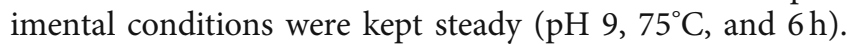
The UV-Vis spectra in Figure 4(a) show the samples of AgNPs in different concentrations. By changing the concentration of silver ion from 0.5 to $1 \mathrm{mM}$, the intensity of SPR peak would be increased significantly, which leads to more silver atoms being generated with high levels of productivity. However, at high concentrations $(1.5 \mathrm{mM})$, the maximum wavelength shifted to the red shift and the peak became broader. This observation could be explained by the assumption that at this concentration, although the rate of reduction was increased, the size of silver particles was increased due to the agglomeration of these clusters. Figure 4(b) shows the TEM image of AgNPs with the concentration of silver nitrate 


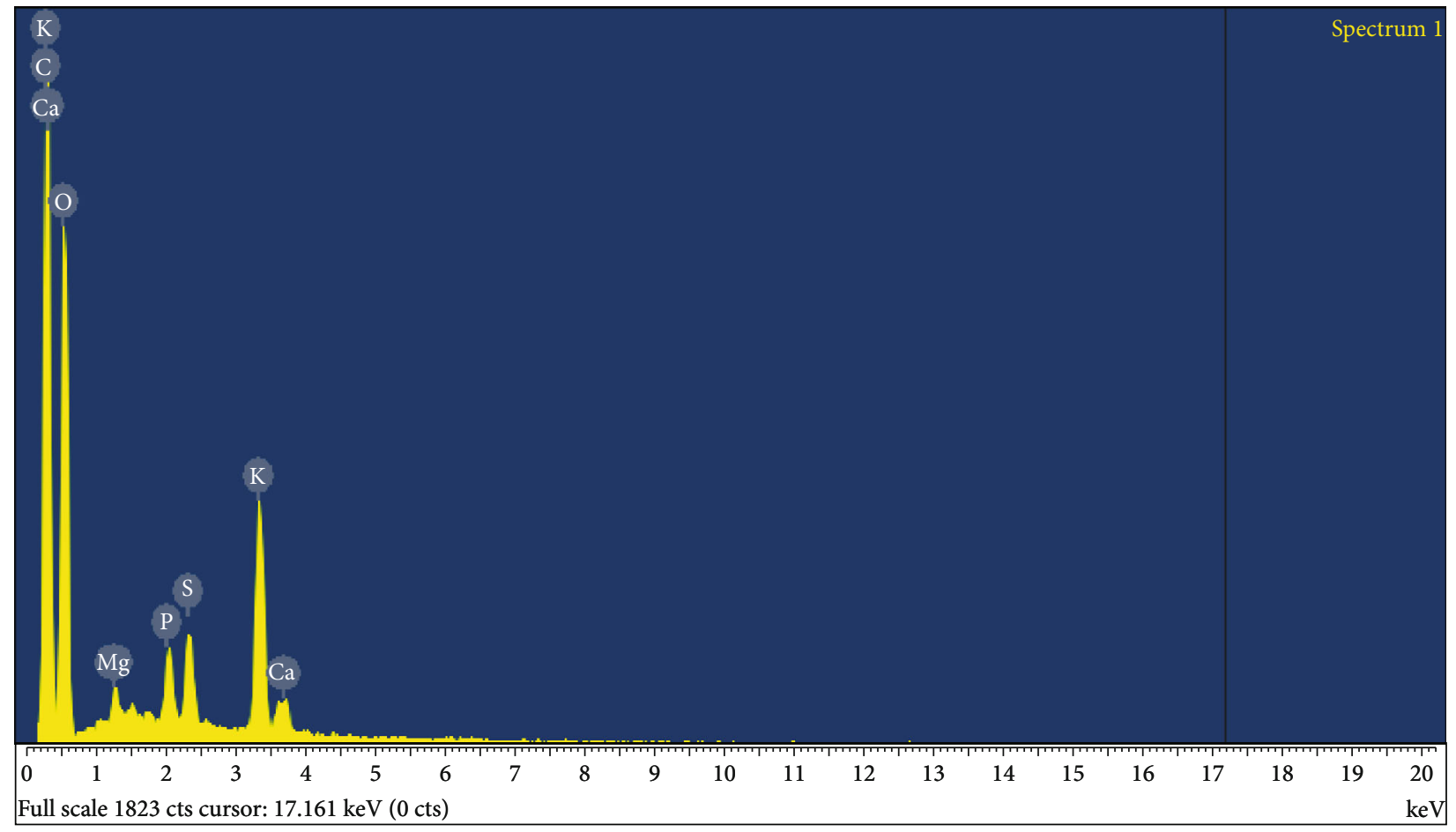

(a)

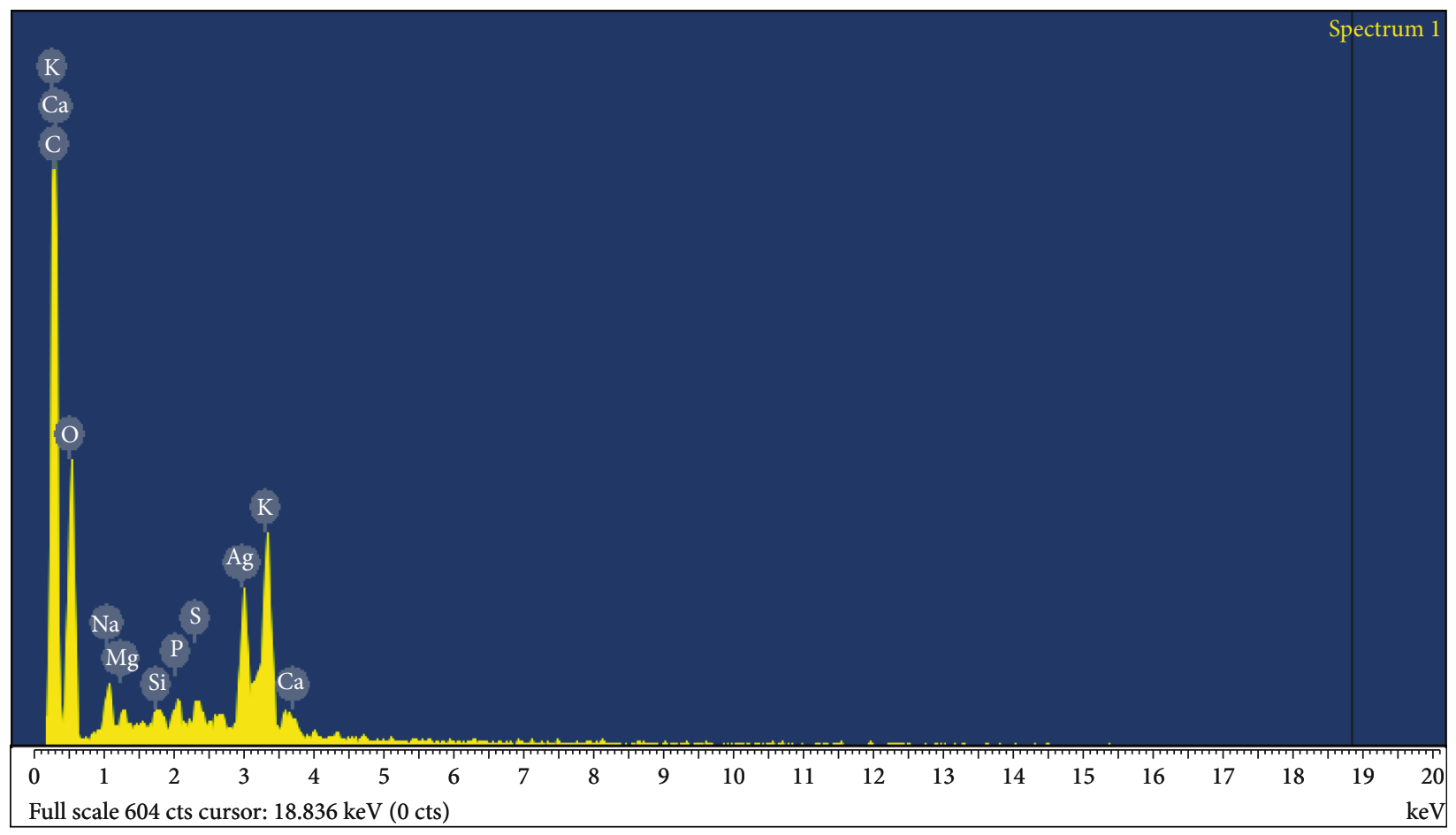

(b)

FIgure 9: The EDX spectrum of (a) GL and (b) AgNPs/GL.

$1.5 \mathrm{mM}$, and it was compared with the sample synthesized at $1 \mathrm{mM}$ (Figure 2(b)). It can be seen that the AgNPs obtained at $1.5 \mathrm{mM}$ were larger and nonuniform, which reasserts that the quantity of ion silver in the reaction solution influenced the agglomeration and the size of AgNPs. Therefore, the optimum concentration of silver nitrate was $1 \mathrm{mM}$.
Reaction temperature is also an important parameter impacting on the synthesis of AgNPs. Hence, four different temperatures from 65 to $95^{\circ} \mathrm{C}$ were investigated and the other parameters were chosen as the optimal values in previous studies. The UV-Vis spectra of silver colloidal solutions at four different temperatures are shown in Figure 5. The result 


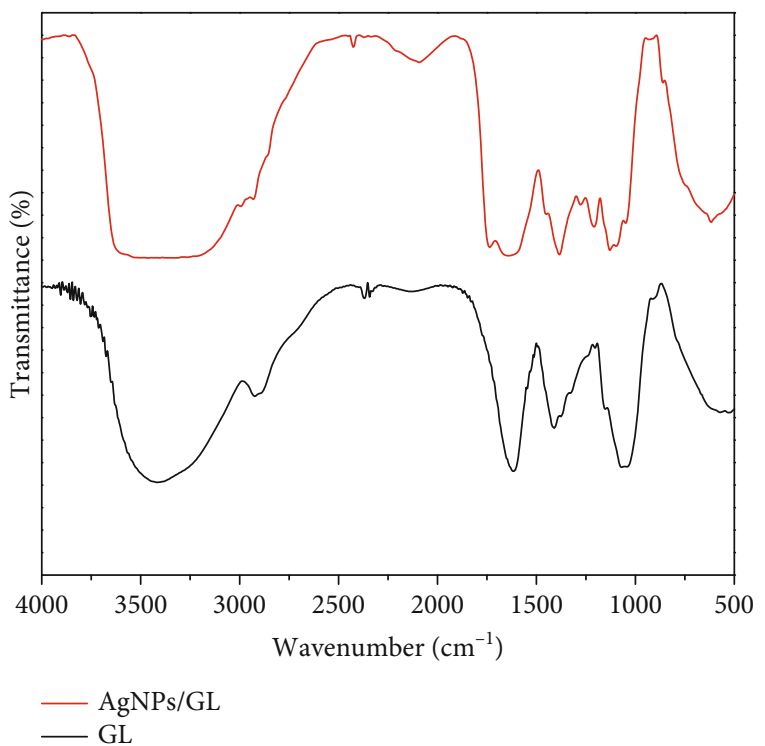

Figure 10: FTIR spectra of AgNPs/GL and GL.

showed that by increasing the synthesis temperature, the SPR peaks of AgNPs shifted to lower wavelengths and had higher intensities. The reason may be that at higher temperatures, not only the reaction rate and the movement of atoms on the solution were increased but also many initial nuclei were created at the same time, which led to a generation of more small particle size [43]. Besides, the UV-Vis spectra of samples synthesized at $85^{\circ} \mathrm{C}$ and above were sharper and this proved that the particles were relatively more uniform [41].

In order to investigate the effect of temperature on the stability of AgNPs, the silver colloidal solutions were retained and determined the maximum absorbance after different storage times. The result showed in Table 1 that, at $85^{\circ} \mathrm{C}$ and higher, the AgNPs obtained were more stable, whereas the AgNPs synthesized at a lower temperature (65 and $75^{\circ} \mathrm{C}$ ) were not stable and agglomerated after 6 weeks. Although the AgNPs synthesized at $95^{\circ} \mathrm{C}$ were not coagulated after 6 weeks, the maximum absorbance was decreased significantly and thus it was less durable than the sample at $85^{\circ} \mathrm{C}$. This reason might be that, at $95^{\circ} \mathrm{C}$ and in alkaline environment, the polysaccharides in fungal aqueous extraction were degraded to smaller weight molecules [44], thereby providing less protection ability and more particles agglomerated. Therefore, in the range of investigated temperature, AgNPs were the most durable at reaction temperature $85^{\circ} \mathrm{C}$ and this temperature was selected as the optimum temperature value. Consequently, the AgNPs/GL were synthesized with optimal condition as follows: $\mathrm{pH}$ 9, silver concentration: $1 \mathrm{mM}$, reaction temperature: $85^{\circ} \mathrm{C}$, and reaction time: $6 \mathrm{~h}$.

3.3. The Stability of the Suspension. In order to evaluate the stability of AgNP/GL colloidal solution, the UV-Vis spectra of the colloidal solution containing the AgNPs synthesized at the optimal conditions were studied at different times at room temperature (Figure 6). The initial sample showed an absorption peak at $409 \mathrm{~nm}$ because of the visual surface plas- mon resonance band of the metallic silver nanomaterial. The intensity of absorption peak slightly decreased after 6 weeks (42 days), which demonstrates that the AgNP/GL colloidal solution is more stable. This phenomenon could be proven that there are some organic compounds in A-GL containing functional groups such as hydroxyl and carbonyl decorating onto the surface of AgNPs; hence, this prevents agglomeration between these particles.

3.4. Characteristics of the Obtained Materials. In optimized synthetic condition, the AgNPs/GL were obtained and characterized with some techniques such as XRD, TEM, EDX, and FTIR.

The X-ray diffraction (XRD) pattern was used to analyze the crystalline nature and identify the phases presented in the prepared sample. The XRD pattern of the AgNPs/GL in Figure 7 presented the typical diffraction peaks at $37.96^{\circ}$, $44.12^{\circ}, 64.26^{\circ}$, and $77.25^{\circ}$ which corresponded to (111), (200), (220), and (311) planes of faced-centered cubic silver (JCPDS card no. 04-0783).

The morphology and particle size of AgNPs/GL were investigated by SEM and TEM techniques. The SEM image showed in Figure 8 that there were AgNPs attaching to the surface of the macromolecule of GL aqueous extract and distributing uniformly. Besides, Figure 8 shows the TEM image of AgNPs/GL revealing the shape and the size distribution of as-prepared nanoparticles and these particles were spherical and quite uniform. These results demonstrated a good agreement with the results of UV-Vis spectra. Moreover, in order to analyze the size distribution of AgNPs, the diameter of approximately 170 particles was determined, and then, the data was demonstrated by a histogram. The diameter of the particle of the AgNPs was around $6.96 \pm 2.29 \mathrm{~nm}$.

The elemental composition was determined by using EDX as presented in Figure 9. The EDX spectrum reveals the purity and the complete chemical composition of silver nanoparticles synthesized. The EDX analysis illustrates the percentage of relative composition of elements found in AgNPs/GL (Figure 9(b)) such as C, O, Mg, P, S, K, Ca, and Ag. In fact, in the composition of AgNPs/GL, there were not only silver metal but also other chemical elements serving as capping organic agent bond to the surface of silver nanoparticles. This phenomenon was verified by the analysis of the composition of aqueous extraction of GL, and the result is shown in Figure 9(a). The composition of GL aqueous extract is similar to the other chemical elements found in the composition of AgNPs/GL.

Figure 10 shows the FTIR spectrum of AgNPs/GL and GL aqueous extract. In the spectra of GL aqueous extraction, the absorption peak observed at $3408 \mathrm{~cm}^{-1}$ was assigned to the stretching vibration of the hydroxyl group. The peak at $2914 \mathrm{~cm}^{-1}$ was attributed to the methylene group, and the peak at $1614 \mathrm{~cm}^{-1}$ could be ascribed to the carbonyl group $(-\mathrm{C}=\mathrm{O})$ stretching vibration considering the presence of hydroxyl hemiacetal groups. In addition, the peak that appeared near $2918 \mathrm{~cm}^{-1}$ confirmed the C-N stretching vibrations of aliphatic amines of protein and the peak at $1415 \mathrm{~cm}^{-1}$ related to the $\mathrm{C}-\mathrm{H}$ bending vibration peak $[45$, 46]. For the spectra of AgNPs/GL, it was exhibited similarity 


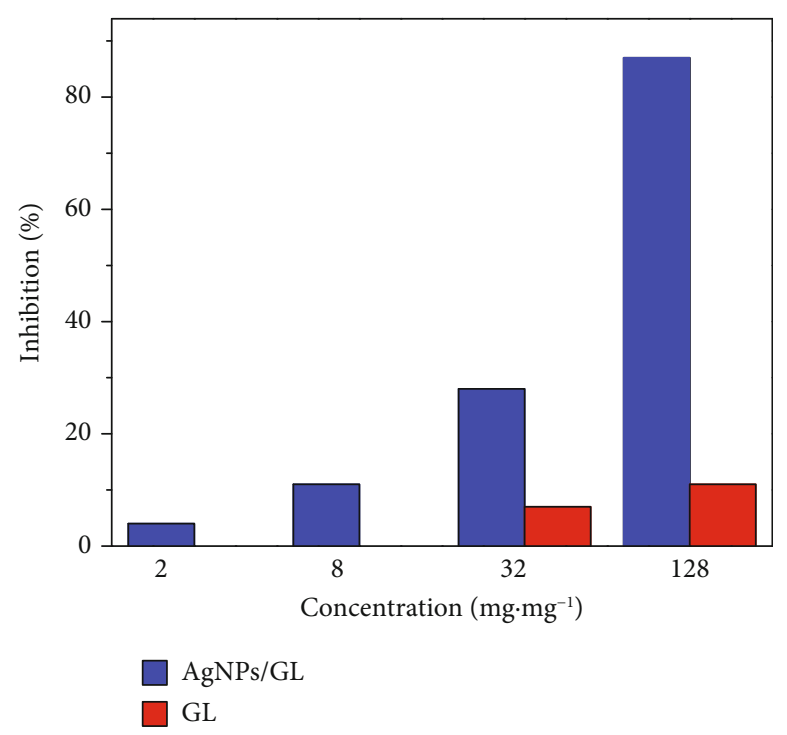

(a)

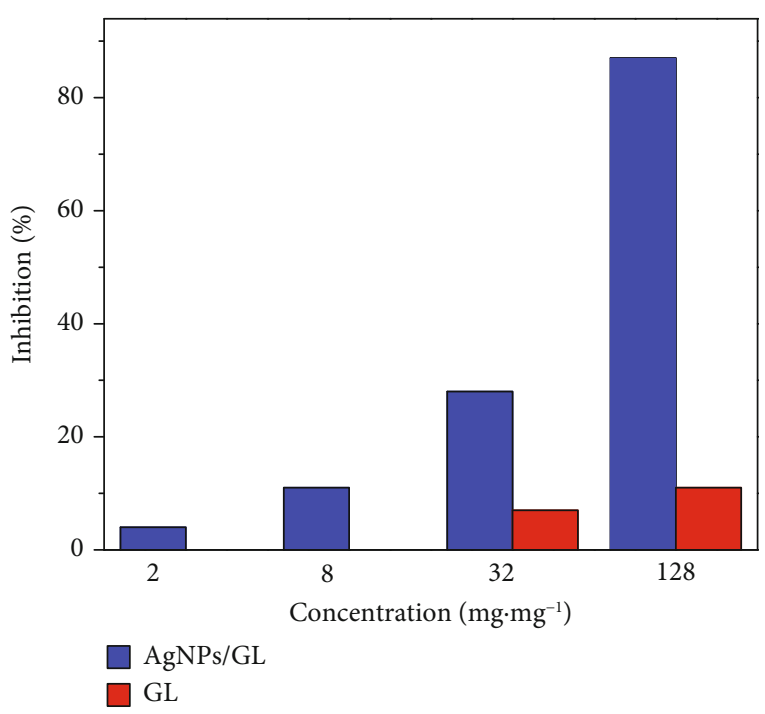

(b)

FIGURE 11: MTT assay results confirming the in vitro cytotoxicity effect of AgNPs/GL and GL aqueous extract with different concentrations against (a) HepG2 cells and (b) MCF-7 cells.

with the FTIR result of GL aqueous extraction and there was a new peak around $1743 \mathrm{~cm}^{-1}$ relating to the carboxylic ester groups. Moreover, the intensity peak of the carbonyl group $\left(\approx 1614 \mathrm{~cm}^{-1}\right)$ was decreased strongly and become wider in comparison with the spectrum of GL aqueous extraction. This observation could be justified by the assumption that some carbonyl groups were oxidized to carboxylic ester groups, which involved reducing ion $\operatorname{Ag}(\mathrm{I})$ to $\operatorname{Ag}(0)$. The FTIR spectroscopic studies illustrated that the presence of functional groups has the ability to form the layer covering the silver nanoparticles to prevent the agglomeration and stabilizing the silver nanoparticles.

3.5. Determination of Cell Viability. The antiproliferative effect of AgNPs/GL and GL aqueous extract was studied by MTT assay in both cell lines (HepG2 and MCF-7), and the results are shown in Figure 11.

Overall, it is clear that AgNPs/GL inhibited effectively the proliferation of HepG2 cells and MCF-7 cells, compared to the inhibitory ability of GL aqueous extract. In terms of HepG2 cells, GL aqueous extract could not inhibit HepG2 cells with concentrations below $32 \mu \mathrm{g} \cdot \mathrm{mL}^{-1}$ and exhibited negligible cytotoxic effect with only $19 \%$ inhibition with $128 \mu \mathrm{g} \cdot \mathrm{mL}^{-1}$. However, in terms of AgNPs/GL, by increasing the concentration from 2 to $128 \mu \mathrm{g} \cdot \mathrm{mL}^{-1}$, the percentage of the inhibition growth rose significantly and reached a peak at $128 \mu \mathrm{g} \cdot \mathrm{mL}^{-1}$ concentration with $97 \%$ inhibition. The same pattern could be seen for the results of MCF-7 cells with a lower percentage of inhibition. Moreover, the $\mathrm{IC}_{50}$ value of AgNPs/GL for HepG2 cells was lower than once for MCF-7 cells with $21.85 \pm 0.2 \mu \mathrm{g} \cdot \mathrm{mL}^{-1}$ and $67.77 \pm 1.44 \mu \mathrm{g} \cdot \mathrm{mL}^{-1}$, respectively. In summary, by utilizing MTT assay for studying the in vitro cytotoxicity, AgNPs/GL seems to reduce the proliferation of HepG2 cells and MCF-7 cells, thereby having potential application on cancer treatment.

\section{Conclusions}

In this study, we demonstrated a novel and easy process for the synthesis of AgNPs using aqueous extraction of G. luci$d u m$. The reaction parameters affecting the particle size and productive reaction such as $\mathrm{pH}$, reaction time, concentration, and temperature were investigated. The results revealed that $\mathrm{pH} 9$, silver concentration of $1 \mathrm{mM}$, reaction temperature at $85^{\circ} \mathrm{C}$, and reaction time of $6 \mathrm{~h}$ were the optimal conditions for the synthesis of AgNPs. The obtained particles were stable and characterized by UV-Vis, SEM, TEM, XRD, EDX, and FTIR. Furthermore, the antiproliferative effect of AgNPs/GL on two cell lines HepG2 and MCF-7 was studied and the results showed that cancer cells were more susceptible to AgNPs/GL with $\mathrm{IC}_{50}$ value of $21.85 \mu \mathrm{g} \cdot \mathrm{mL}^{-1}$ for HepG2 and $67.77 \mu \mathrm{g} \cdot \mathrm{mL}^{-1}$ for MCF-7. The results proposed a potential of utilizing AgNPs/GL in the medical fields, especially cancer treatment in two cell lines HepG2 and MCF-7.

\section{Data Availability}

Data is available upon reasonable request.

\section{Conflicts of Interest}

There are no conflicts of interest to declare.

\section{Acknowledgments}

Vinh Phu Nguyen was funded by Vingroup Joint Stock Company and supported by the Domestic Master/PhD Scholarship Programme of Vingroup Innovation Foundation (VINIF), Vingroup Big Data Institute (VINBIGDATA), code VINIF.2020.ThS.38. 


\section{References}

[1] J. M. Llovet, C. E. A. Peña, C. D. Lathia et al., "Plasma biomarkers as predictors of outcome in patients with advanced hepatocellular carcinoma," Clinical Cancer Research, vol. 18, no. 8, pp. 2290-2300, 2012.

[2] N. Harbeck, F. Penault-Llorca, J. Cortes et al., "Breast cancer," Nature Reviews Disease Primers, vol. 5, no. 1, p. 66, 2019.

[3] Z. Li, S. Tan, S. Li, Q. Shen, and K. Wang, "Cancer drug delivery in the nano era: an overview and perspectives," Oncology Reports, vol. 38, no. 2, pp. 611-624, 2017.

[4] K. Cho, X. U. Wang, S. Nie, Z. G. Chen, and D. M. Shin, “Therapeutic nanoparticles for drug delivery in cancer," Clinical Cancer Research, vol. 14, no. 5, pp. 1310-1316, 2008.

[5] F.-Y. Kong, J.-W. Zhang, R.-F. Li, Z.-X. Wang, W.-J. Wang, and W. Wang, "Unique roles of gold nanoparticles in drug delivery, targeting and imaging applications," Molecules, vol. 22, no. 9, p. 1445, 2017.

[6] J. E. Millstone, S. J. Hurst, G. S. Métraux, J. I. Cutler, and C. A. Mirkin, "Colloidal gold and silver triangular nanoprisms," Small, vol. 5, no. 6, pp. 646-664, 2009.

[7] S. H. Lee, W.-Y. Rho, S. J. Park, J. Kim, O. S. Kwon, and B.H. Jun, "Multifunctional self-assembled monolayers via microcontact printing and degas-driven flow guided patterning," Scientific Reports, vol. 8, p. 1, 2018.

[8] S. H. Lee, J. H. Sung, and T. H. Park, "Nanomaterial-based biosensor as an emerging tool for biomedical applications," Annals of Biomedical Engineering, vol. 40, no. 6, pp. 13841397, 2012.

[9] G. Vinci and M. Rapa, "Noble metal nanoparticles applications: recent trends in food control," Bioengineering, vol. 6, no. 1, p. 10, 2019.

[10] M. Vaseem, K. M. Lee, A.-R. Hong, and Y.-B. Hahn, "Inkjet printed fractal-connected electrodes with silver nanoparticle ink," ACS Applied Materials \& Interfaces, vol. 4, no. 6, pp. 3300-3307, 2012.

[11] J. García-Barrasa, J. López-de-Luzuriaga, and M. Monge, "Silver nanoparticles: synthesis through chemical methods in solution and biomedical applications," Open Chemistry, vol. 9, no. 1, pp. 7-19, 2011.

[12] W. Xu, W. Jin, L. Lin et al., "Green synthesis of xanthan conformation-based silver nanoparticles: antibacterial and catalytic application," Carbohydrate Polymers, vol. 101, pp. 961$967,2014$.

[13] V. Pifferi, V. Marona, M. Longhi, and L. Falciola, "Characterization of polymer stabilized silver nanoparticles modified glassy carbon electrodes for electroanalytical applications," Electrochimica Acta, vol. 109, pp. 447-453, 2013.

[14] V. K. Sharma, R. A. Yngard, and Y. Lin, "Silver nanoparticles: green synthesis and their antimicrobial activities," Advances in Colloid and Interface Science, vol. 145, no. 1-2, pp. 83-96, 2009.

[15] Y. Xue, T. Zhang, B. Zhang, F. Gong, Y. Huang, and M. Tang, "Cytotoxicity and apoptosis induced by silver nanoparticles in human liver HepG2 cells in different dispersion media," Journal of Applied Toxicology, vol. 36, no. 3, pp. 352-360, 2016.

[16] S. Khorrami, A. Zarrabi, M. Khaleghi, M. Danaei, and M. R. Mozafari, "Selective cytotoxicity of green synthesized silver nanoparticles against the MCF-7 tumor cell line and their enhanced antioxidant and antimicrobial properties," International Journal of Nanomedicine, vol. 13, pp. 8013-8024, 2018.
[17] Y. Jeong, D. W. Lim, and J. Choi, "Assessment of sizedependent antimicrobial and cytotoxic properties of silver nanoparticles," Advances in Materials Science and Engineering, vol. 2014, Article ID 763807, 6 pages, 2014.

[18] S. H. Lee and B.-H. Jun, "Silver nanoparticles: synthesis and application for nanomedicine," International Journal of Molecular Sciences, vol. 20, no. 4, p. 865, 2019.

[19] F. Mafuné, J. Kohno, Y. Takeda, T. Kondow, and H. Sawabe, "Formation and size control of silver nanoparticles by laser ablation in aqueous solution," The Journal of Physical Chemistry. B, vol. 104, no. 39, pp. 9111-9117, 2000.

[20] P. Slepička, R. Elashnikov, P. Ulbrich, M. Staszek, Z. Kolská, and V. Švorčík, "Stabilization of sputtered gold and silver nanoparticles in PEG colloid solutions," Journal of Nanoparticle Research, vol. 17, no. 1, p. 11, 2015.

[21] B. Nair and T. Pradeep, "Coalescence of Nanoclusters and Formation of Submicron Crystallites Assisted byLactobacillusStrains," Crystal Growth \& Design, vol. 2, no. 4, pp. 293-298, 2002.

[22] V. V. Makarov, A. J. Love, O. V. Sinitsyna et al., ““Green” nanotechnologies: synthesis of metal nanoparticles using plants," Acta Naturae, vol. 6, no. 1, pp. 35-44, 2014.

[23] A. Mohammed Fayaz, K. Balaji, P. T. Kalaichelvan, and R. Venkatesan, "Fungal based synthesis of silver nanoparticles-An effect of temperature on the size of particles," Colloids Surfaces B Biointerfaces, vol. 74, no. 1, pp. 123-126, 2009.

[24] J. Venkatesan, S.-K. Kim, and M. S. Shim, "Antimicrobial, antioxidant, and anticancer activities of biosynthesized silver nanoparticles using marine algae Ecklonia cava," Nanomaterials, vol. 6, no. 12, p. 235, 2016.

[25] R. Mie, M. W. Samsudin, L. B. Din, A. Ahmad, N. Ibrahim, and S. N. A. Adnan, "Synthesis of silver nanoparticles with antibacterial activity using the lichen Parmotrema praesorediosum," International Journal of Nanomedicine, vol. 9, p. 121, 2014.

[26] K. Paulkumar, G. Gnanajobitha, M. Vanaja et al., "Piper nigrum leaf and stem assisted green synthesis of silver nanoparticles and evaluation of its antibacterial activity against agricultural plant pathogens," The Scientific World Journal, vol. 2014, Article ID 829894, 9 pages, 2014.

[27] A. Roy, O. Bulut, S. Some, A. K. Mandal, and M. D. Yilmaz, "Green synthesis of silver nanoparticles: biomoleculenanoparticle organizations targeting antimicrobial activity," RSC Advances, vol. 9, no. 5, pp. 2673-2702, 2019.

[28] M. Ghaffari-Moghaddam, R. Hadi-Dabanlou, M. Khajeh, M. Rakhshanipour, and K. Shameli, "Green synthesis of silver nanoparticles using plant extracts," Korean Journal of Chemical Engineering, vol. 31, no. 4, pp. 548-557, 2014.

[29] M. Rafique, I. Sadaf, M. S. Rafique, and M. B. Tahir, “A review on green synthesis of silver nanoparticles and their applications," Artificial Cells, Nanomedicine, and Biotechnology, vol. 45, no. 7, pp. 1272-1291, 2017.

[30] K. S. Bishop, C. H. J. Kao, Y. Xu, M. P. Glucina, R. R. M. Paterson, and L. R. Ferguson, "From 2000 years of Ganoderma lucidum to recent developments in nutraceuticals," Phytochemistry, vol. 114, pp. 56-65, 2015.

[31] B. Boh, M. Berovic, J. Zhang, and L. Zhi-Bin, "Ganoderma lucidum and its pharmaceutically active compounds," Biotechnology Annual Review, vol. 13, pp. 265-301, 2007.

[32] K. Tasaka, M. Akagi, K. Miyoshi, M. Mio, and T. Makino, "Anti-allergic constituents in the culture medium of Ganoderma lucidum.(I) Inhibitory effect of oleic acid on histamine 
release," Agents and Actions, vol. 23, no. 3-4, pp. 153-156, 1988.

[33] S. Joseph, B. Sabulal, V. George, K. Antony, and K. Janardhanan, "Antitumor and anti-inflammatory activities of polysaccharides isolated from Ganoderma lucidum," Acta Pharmaceutica, vol. 61, no. 3, pp. 335-342, 2011.

[34] S.-K. K. Eo, Y.-S. S. Kim, C.-K. K. Lee, and S.-S. S. Han, “Antiviral activities of various water and methanol soluble substances isolated from Ganoderma lucidum," Journal of Ethnopharmacology, vol. 68, no. 1-3, pp. 129-136, 1999.

[35] C. Kao, A. C. Jesuthasan, K. S. Bishop, M. P. Glucina, and L. R. Ferguson, "Anti-cancer activities of Ganoderma lucidum: active ingredients and pathways," Functional Foods in Health and Disease, vol. 3, no. 2, pp. 48-65, 2013.

[36] H.-T. Ma, J.-F. Hsieh, and S.-T. Chen, "Anti-diabetic effects of Ganoderma lucidum," Phytochemistry, vol. 114, pp. 109-113, 2015.

[37] S. Manickam, K. Muthoosamy, R. G. Bai et al., "Exceedingly biocompatible and thin-layered reduced graphene oxide nanosheets using an eco-friendly mushroom extract strategy," International Journal of Nanomedicine, vol. 10, p. 1505, 2015.

[38] F. Faedmaleki, F. H Shirazi, A.-A. Salarian, H. Ahmadi Ashtiani, and H. Rastegar, "Toxicity effect of silver nanoparticles on mice liver primary cell culture and HepG2 cell line," Iranian Journal of Pharmaceutical Research, vol. 13, no. 1, pp. 235-242, 2014.

[39] D. A. Scudiero, R. H. Shoemaker, K. D. Paull et al., "Evaluation of a soluble tetrazolium/formazan assay for cell growth and drug sensitivity in culture using human and other tumor cell lines," Cancer Research, vol. 48, no. 17, pp. 4827-4833, 1988.

[40] R. I. Freshney and M. G. Freshney, Culture of Epithelial Cells, John Wiley \& Sons, 2004.

[41] R. Seifipour, M. Nozari, and L. Pishkar, "Green synthesis of silver nanoparticles using Tragopogon collinus leaf extract and study of their antibacterial effects," Journal of Inorganic and Organometallic Polymers and Materials, vol. 30, no. 8, pp. 2926-2936, 2020.

[42] M. Sathishkumar, K. Sneha, S. W. Won, C.-W. Cho, S. Kim, and Y.-S. Yun, "Cinnamon zeylanicum bark extract and powder mediated green synthesis of nano-crystalline silver particles and its bactericidal activity," Colloids Surfaces B Biointerfaces, vol. 73, no. 2, pp. 332-338, 2009.

[43] B. Sumi Maria, A. Devadiga, V. Shetty Kodialbail, and M. B. Saidutta, "Synthesis of silver nanoparticles using medicinal Zizyphus xylopyrus bark extract," Applied Nanoscience, vol. 5, no. 6, pp. 755-762, 2015.

[44] B. Wu, Q. H. Feng, L. L. Geng, K. W. Shu, and D. Zhang, "Study on the optimal hydrolysis conditions of Ganoderma lucidum spore powder under microwave irradiation," Advanced Materials Research, vol. 900, pp. 293-296, 2014.

[45] M. Ibrahim, M. Alaam, H. el-Haes, A. F. Jalbout, and A. De Leon, "Analysis of the structure and vibrational spectra of glucose and fructose," Eclética Química, vol. 31, no. 3, pp. 15-21, 2006.

[46] J. Wang and L. Zhang, "Structure and chain conformation of five water-soluble derivatives of a $\beta$-d- glucan isolated from Ganoderma lucidum," Carbohydrate Research, vol. 344, no. 1, pp. 105-112, 2009. 